\title{
9. VARIATION OF BASALT PHENOCRYST MINERALOGY AND ROCK COMPOSITIONS IN DSDP HOLE 396B
}

\author{
Henry J.B. Dick and Wilfred B. Bryan, Woods Hole Oceanographic Institution, Woods Hole, Massachusetts
}

\begin{abstract}
Data are presented on phenocryst proportions and content for 40 basalts representative of the stratigraphic section drilled at DSDP Hole 396B, and olivine and spinel phenocryst microprobe analyses for all basalts. The variations of phenocryst proportions, content, and composition with whole rock composition and stratigraphic position of the basalts are used to infer their petrogenesis. On the basis of the colinearity of aphyric and phenocryst-free basalt compositions, it appears that crystallization of the Hole 396B basalts was controlled by a low-pressure cotectic. Phenocryst proportions vary irregularly in the basalts, indicating that gravity separation of phenocrysts occurred due to flotation of plagioclase and sinking of olivine. The proportion of olivine which must have crystallized from one Hole $396 \mathrm{~B}$ unit in order to account for the range in olivine phenocryst compositions in the basalts is the same as that expected from the present plagioclase phenocryst content for crystallization along the low-pressure cotectic. Irregular variations in melt composition and $\mathrm{fO}_{2}$ (as indicated by olivine and spinel microphenocryst compositions) and the presence of normally and reversely zoned phenocrysts in the same sample, suggest periodic mixing of new magma with old. All these features and the large irregular stratigraphic variation of basalt compositions and mineralogy within a pillow unit can be explained if the Hole 396B pillow lavas tapped different portions of a heterogeneous magma chamber. Heterogeneity in the chamber would arise as a consequence of the introduction of new melt and due to gravitational sorting of phenocrysts. The abrupt changes in composition and mineralogy of the basalt and the presence of sediment and weathering at the contacts of the various Hole $396 \mathrm{~B}$ pillow basalt units suggest that volcanic activity was periodic at this site, possibly triggered or controlled by intermittent earthquake swarms and fissuring along this portion of the old ridge axis. The differences in chemistry and mineralogy of the different units are probably the consequence of a random combination of fractional crystallization and magma mixing or the formation of a new magma chamber between cycles of volcanic activity.
\end{abstract}

\section{INTRODUCTION}

Unlike dredged samples, DSDP cores provide a stratigraphic section permitting the study of the local evolution of ridge basalts with time. This chapter reports the petrology and modal phenocryst mineralogy of 40 DSDP Leg 46, Hole 396B basalt samples, and olivine and spinel compositions from 11 of these basalts. These samples represent the 255-meter section of basaltic basement drilled at $22^{\circ} 59^{\prime} \mathrm{N}, 43^{\circ} 31^{\prime} \mathrm{W}, 160 \mathrm{~km}$ east of the Mid-Atlantic Ridge in $10-\mathrm{m} . \mathrm{y}$. old ocean crust. The samples were taken adjacent to those selected for shipboard X-ray fractionation (XRF) analysis of major and trace elements to examine the variations in phenocryst proportions and composition in relation to whole rock chemistry. One XRF analysis from the shipboard study (No. 19) has not been used here as it is

${ }^{1}$ Woods Hole Contribution No. 40602. anomalously low in $\mathrm{MgO}$ compared to other analyses of rocks with similar mineralogy in the same unit.

\section{PETROGRAPHY}

The Hole 396B basalts can be subdivided into a series of seven distinct units (Table 1) on the basis of their petrography, as well as on their chemistry and magnetic inclinations (Site Chapter, this volume). All of these units, with the exception of Units 4 and 7, contain 3 per cent plagioclase and/or olivine phenocrysts (Table 1). Units 4 and 7 contain 9 to 25 per cent plagioclase and subordinate olivine phenocrysts. No clinopyroxene phenocrysts were seen in the 40 thin sections examined. Spinel is present as an accessory phase in only 19 thin sections. The groundmass consists of plagioclase, clinopyroxene, glass, and occasional olivine. Opaques, presumably titanomagnetite, were present in nearly every thin section as a late interstitial phase in amounts up to 2 per cent or more. Both the grain size and abundance of 
TABLE 1

Hole 396B Basalts

\begin{tabular}{|c|c|c|c|c|c|c|c|c|}
\hline $\begin{array}{c}\text { Sample } \\
\text { (Interval in } \mathrm{cm} \text { ) }\end{array}$ & $\begin{array}{c}\mathrm{Fe}_{2} \mathrm{O}_{3} \\
(\%)\end{array}$ & $\begin{array}{l}\mathrm{TiO}_{2} \\
(\%)\end{array}$ & $\underset{(\%)}{\mathrm{Al}_{2} \mathrm{O}_{3}}$ & $\begin{array}{c}\mathrm{Cr} \\
\text { (ppm) }\end{array}$ & $\begin{array}{r}01 \\
(\%)\end{array}$ & $\begin{array}{l}\mathrm{Pg} \\
(\%)\end{array}$ & $\mathrm{Sp}$ & Notes \\
\hline \multicolumn{9}{|l|}{ Unit 1} \\
\hline $\begin{array}{l}4-1,103-105 \\
5-1,86-88 \\
5-2,51-53 \\
6-1,55-57 \\
7-1,53-55 \\
7-1,132-134 \\
8-1,62-64 \\
8-2,60-62 \\
10-1,51-53 \\
11-1,56-68 \\
11-2,5-7 \\
12-1,127-129 \\
13-1,45-57 \\
13-2,49-51 \\
13-2,89-91\end{array}$ & $\begin{array}{r}10.3 \\
10.0 \\
10.2 \\
9.6 \\
10.5 \\
10.4 \\
10.6 \\
10.3 \\
10.9 \\
10.7 \\
10.6 \\
10.5 \\
10.7 \\
10.3 \\
10.3\end{array}$ & $\begin{array}{l}1.43 \\
1.37 \\
1.40 \\
1.44 \\
1.42 \\
1.42 \\
1.51 \\
1.55 \\
1.54 \\
1.54 \\
1.54 \\
1.51 \\
1.53 \\
1.51 \\
1.51\end{array}$ & $\begin{array}{l}15.5 \\
15.7 \\
15.3 \\
16.1 \\
15.6 \\
15.3 \\
15.4 \\
15.3 \\
15.4 \\
15.3 \\
15.4 \\
15.1 \\
15.3 \\
15.1 \\
15.4\end{array}$ & $\begin{array}{l}355 \\
358 \\
327 \\
341 \\
357 \\
345 \\
308 \\
293 \\
319 \\
310 \\
292 \\
296 \\
323 \\
300 \\
300\end{array}$ & $\begin{aligned} & 0.5 \\
&<1<1 \\
&<1 \\
&<1 \\
&<1 \\
&<1 \\
& \quad 0.6 \\
& 0.2 \\
&<1 \\
&<1 \\
&<1 \\
&<1 \\
&<1 \\
&<1 \\
& \quad-\end{aligned}$ & $\begin{array}{l}0.6 \\
\ll 1 \\
- \\
- \\
- \\
- \\
1.4 \\
0.4 \\
1.0 \\
<1 \\
- \\
<1 \\
<1 \\
<1 \\
-\end{array}$ & $\begin{array}{l}- \\
- \\
- \\
- \\
- \\
- \\
- \\
\operatorname{tr} \\
\operatorname{tr} \\
- \\
- \\
\operatorname{tr} \\
- \\
- \\
-\end{array}$ & $\begin{array}{l}\text { Euhedral olivine } \\
0.5-3 \mathrm{~mm} \text {, and occasional } \\
\text { rounded and resorbed } \\
\text { olivine xenocrysts; } \\
\text { euhedral plagioclase } \\
1-2.5 \mathrm{~mm} \text {, and occasional } \\
\text { plagioclase xenocrysts } \\
1-6 \mathrm{~mm} \text {; spinel xenocrysts }\end{array}$ \\
\hline \multicolumn{9}{|l|}{ Unit 2} \\
\hline $\begin{array}{l}13-3,4-6 \\
14-2,17-19\end{array}$ & $\begin{array}{l}10.6 \\
10.8\end{array}$ & $\begin{array}{l}1.67 \\
1.64\end{array}$ & $\begin{array}{l}15.5 \\
15.3\end{array}$ & $\begin{array}{l}297 \\
297\end{array}$ & $\begin{array}{l}<1 \\
<1\end{array}$ & $\begin{array}{r}<1 \\
-\end{array}$ & $\overline{-}$ & $\begin{array}{l}\text { Occasional } 1 \mathrm{~mm} \text { euhedral } \\
\text { olivine and/or rounded } \\
\text { plagioclase xenocryst }\end{array}$ \\
\hline \multicolumn{9}{|l|}{ Unit 3} \\
\hline $\begin{array}{l}15-1,85-87 \\
15-2,129-131 \\
15-3,16-19 \\
15-4,76-79 \\
15-5,70-73\end{array}$ & $\begin{array}{l}11.0 \\
11.2 \\
11.0 \\
11.2 \\
11.2\end{array}$ & $\begin{array}{l}1.65 \\
1.63 \\
1.63 \\
1.63 \\
1.61\end{array}$ & $\begin{array}{l}15.1 \\
15.0 \\
15.2 \\
15.0 \\
15.1\end{array}$ & $\begin{array}{l}285 \\
266 \\
263 \\
267 \\
266\end{array}$ & $\begin{array}{l}0.3 \\
- \\
- \\
-\end{array}$ & $\begin{array}{l}0.4 \\
- \\
0.6 \\
2.7\end{array}$ & $\begin{array}{l}- \\
\overline{-} \\
-\end{array}$ & $\begin{array}{l}\text { Occasional euhedral } \\
\text { olivine } \sim 1 \mathrm{~mm} \text { and an } \\
\text { occasional rounded } \\
\text { plagioclase xenocryst }\end{array}$ \\
\hline $\begin{array}{l}\text { Unit } 4 \\
16-1,83-85 \\
16-2,40-42 \\
16-4,20-22 \\
16-5,96-98 \\
17-1,132-134 \\
18-1,117-119 \\
19-1,4-6 \\
20-1,53-55 \\
20-3,33-35 \\
20-5,16-18 \\
21-2,24-26 \\
22-1,93-95\end{array}$ & $\begin{array}{r}9.2 \\
9.5 \\
10.0 \\
9.2 \\
9.5 \\
9.4 \\
10.5 \\
8.8 \\
8.7 \\
9.1 \\
8.6 \\
8.5\end{array}$ & $\begin{array}{l}1.20 \\
1.20 \\
1.33 \\
1.21 \\
1.21 \\
1.21 \\
1.33 \\
1.04 \\
1.10 \\
1.16 \\
1.01 \\
0.99\end{array}$ & $\begin{array}{l}16.9 \\
16.7 \\
16.9 \\
17.1 \\
16.9 \\
17.0 \\
19.1 \\
17.6 \\
17.3 \\
17.7 \\
17.7 \\
18.0\end{array}$ & $\begin{array}{l}323 \\
325 \\
347 \\
320 \\
335 \\
339 \\
359 \\
326 \\
347 \\
364 \\
356 \\
363\end{array}$ & $\begin{array}{l}3.2 \\
2.6 \\
2.1 \\
3.6 \\
4.2 \\
4.0 \\
2.4 \\
2.8 \\
3.0 \\
1.3 \\
5.4 \\
4.2\end{array}$ & $\begin{array}{l}16.7 \\
19.2 \\
11.2 \\
13.2 \\
14.9 \\
12.1 \\
14.8 \\
17.2 \\
16.0 \\
10.9 \\
19.7 \\
19.5\end{array}$ & $\begin{array}{l}\mathrm{tr} \\
\mathrm{tr} \\
\mathrm{tr} \\
\mathrm{tr} \\
\mathrm{tr} \\
\mathrm{tr} \\
\mathrm{tr} \\
\mathrm{tr} \\
\mathrm{tr} \\
\mathrm{tr} \\
\mathrm{tr} \\
\mathrm{tr}\end{array}$ & $\begin{array}{l}\text { Euhedral olivine } \\
0.5-10 \mathrm{~mm}(\text { avg. } 1 \mathrm{~mm}) \\
\text { euhedral plagioclase } \\
0.5-5 \mathrm{~mm} \text { (avg. } 2 \mathrm{~mm}) \text {; } \\
\text { Plagioclase xenocrysts } \\
\text { common with either a } \\
\text { rounded or spongy re- } \\
\text { sorbed appearance with } \\
\text { an avg. size of } 3-10 \mathrm{~mm}\end{array}$ \\
\hline \multicolumn{9}{|l|}{ Unit 5} \\
\hline $\begin{array}{l}23-1,27-30 \\
23-1,72-78 \\
24-1,98-100\end{array}$ & $\begin{array}{l}10.58 \\
10.45\end{array}$ & $\begin{array}{l}1.58 \\
1.54\end{array}$ & $\begin{array}{l}16.01 \\
16.06\end{array}$ & $\begin{array}{l}346 \\
345\end{array}$ & $\begin{array}{l}1 \\
0.7 \\
0.9\end{array}$ & $\begin{array}{l}1 \\
0.8 \\
0.4\end{array}$ & $\begin{array}{l}\mathrm{tr} \\
\mathrm{tr} \\
\mathrm{tr}\end{array}$ & $\begin{array}{l}0.5-2 \mathrm{~mm} \text { euhedral } \\
\text { olivine } 3-5 \mathrm{~mm} \text { rounded } \\
\text { and spongy appearing } \\
\text { plagioclase xenocrysts }\end{array}$ \\
\hline \multicolumn{9}{|l|}{ Unit 6} \\
\hline $\begin{array}{l}26-1,7-10 \\
30-1,77-80\end{array}$ & 10.3 & 1.49 & 15.9 & 358 & $\begin{array}{l}1.1 \\
0.8\end{array}$ & $\begin{array}{l}0.9 \\
2.4\end{array}$ & $\operatorname{tr}$ & $\begin{array}{l}\text { Euhedral olivine } \\
0.5-5 \mathrm{~mm} \text { (avg. } 0.7 \mathrm{~mm}) \\
0.5-1 \mathrm{~mm} \text { rounded and } \\
\text { ragged plagioclase xeno- } \\
\text { crysts and a few euhedral; } \\
\text { One large anhedral spinel }\end{array}$ \\
\hline \multicolumn{9}{|l|}{ Unit 7} \\
\hline $\begin{array}{l}32-1,45-47 \\
32-1,69-71\end{array}$ & $\begin{array}{l}10.9 \\
10.27\end{array}$ & $\begin{array}{l}1.45 \\
1.22\end{array}$ & $\begin{array}{l}15.9 \\
18.0\end{array}$ & $\begin{array}{l}350 \\
348\end{array}$ & $\begin{array}{l}0.7 \\
1.1\end{array}$ & $\begin{array}{l}9.6 \\
8.2\end{array}$ & $\overline{\operatorname{tr}}$ & $\begin{array}{l}\text { Euhedral olivine }<0.5 \mathrm{~mm} \text {; } \\
\text { large euhedral plagioclase } \\
\text { and rounded xenocrysts }\end{array}$ \\
\hline
\end{tabular}

${ }^{\mathrm{a}}$ Percentage of olivine and plagioclase phenocrysts estimated by point counting a single thin section minimum of 1000 points.

${ }^{b}$ Internal Sample numbers used in figures. 
titanomagnetite appear to depend more on the degree of crystallinity than on any other factor.

Phenocryst proportions and content have at times proved to be a useful means of classifying oceanic basalts (Miyashiro et al., 1970; Hekinian et al., 1976). This method is not without pitfalls, particularly where phenocryst contents are small and modal analyses are based on a limited area. Modal data on phenocryst contents of basalts from Hole 396B are presented in Table 1. These analyses each represent approximately a thousand points covering a $6-\mathrm{cm}^{2}$ area on a single thin section. Though it would be preferable to have counted several sections from different orientations for each basalt, this was not possible due to the limited amount of material available. Where the total phenocryst content is $<5$ per cent, the proportions quoted in Table 1 should be regarded as a rough estimate only.

Plagioclase phenocrysts range from euhedral microphenocrysts to grains up to a centimeter across. Glomerocrysts of olivine and plagioclase are present in many thin sections. Individual phenocrysts range from large euhedra to heavily corroded and rounded xenocrysts (phenocrysts clearly not in equilibrium with the liquid) sometimes with vermiform inclusions at their margins, often both types occur in the same thin section. In Units 3, 4 and 5 , plagioclase appears to be largely xenocrystal in the presence of euhedral olivine phenocrysts and microphenocrysts. In Unit 4, where plagioclase phenocrysts are most abundant, many of the xenocrystal grains contain numerous glass or matrix-filled holes and have a "spongy", appearance. As discussed by Dungan et al. (this volume), plagioclase phenocrysts may be either reversely or normally zoned in the same thin section.

Olivine phenocrysts total 1 per cent or less in all the units except Unit 4 where they occur in amounts up to 5 and 6 per cent. Euhedral grains are most common, averaging about 0.75 to $1.0 \mathrm{~mm}$, with rare grains as large as $10 \mathrm{~mm}$. Rounded, apparently resorbed xenocrysts do occur, most frequently in Unit 1. Large amoeboid skeletal olivine grains, often intergrown with plagioclase phenocrysts, occur in Unit 5; this texture is thought to indicate extremely rapid growth (Gutmann, 1977).

Spinel occurs as a rare accessory phase in Unit 1, where it generally is found as inclusions in olivine or plagioclase phenocrysts, or as rounded and partly resorbed xenocrysts up to $0.4 \mathrm{~mm}$ diameter in the groundmass. Spinel is absent in the nearly holocrystalline Units 2 and 3. In Units 4 and 5, spinel is present as small euhedra from 5 to $20 \mu \mathrm{m}$ across and as larger, usually anhedral, xenocrysts up to $0.5 \mathrm{~mm}$ across. Both varieties are found in most thin sections. Some of the larger grains contain numerous holes at their margins which are filled with vermiform glass and matrix inclusions; this texture is thought typical of rapid resorption. Spinel from Units 4 and 5 occurs as clusters or chains in some thin sections, in addition to isolated inclusions in phenocrysts and groundmass.

The occurrence of chromian spinel in Hole $396 \mathrm{~B}$ basalts appears to be favored by high $\mathrm{Cr}$, low $\mathrm{FeO}^{*} /\left(\mathrm{FeO}^{*}+\right.$ $\mathrm{MgO}$ ), and (possibly) high $\mathrm{Al}_{2} \mathrm{O}_{3}$ (Table 4), as found by Sigurdsson (1977) for DSDP Leg 37 basalts. Many basalts with $\mathrm{Cr}$ contents above $300 \mathrm{ppm}$, however, do not have spinel, suggesting that $\mathrm{Cr}$ content alone does not control the presence of spinel.

\section{OLIVINE CHEMISTRY}

Analyses of 37 olivine phenocrysts and microphenocrysts from eight Hole 396B basalts are given in Table 2. All the analyses were done with the Massachusetts Institute of Technology electron microprobe. Natural standards were used for all elements: olivine (\# P-140) for $\mathrm{Mg}, \mathrm{Fe}$, and $\mathrm{Si}$; diopside for $\mathrm{Ca}$; and manganese ilmenite for $\mathrm{Mn}$ and $\mathrm{Ti}$. Estimates of precision are given in Table 2 (and Table 3) based on repetitive analyses of a single standard grain made throughout the course of analysis. This estimate does not allow for errors due to variations in the thickness of carbon coatings between samples and standards.

Olivine ranges in composition from Fo85. o to Fo89. 5, with a range of composition in each thin section examined. As seen in Figure 1, there is a rough correlation between the apparent grain size and forsterite content, with the smallest olivine crystals having the highest iron contents.

\section{SPINEL CHEMISTRY}

Analyses of 28 spinels from 11 Hole $396 \mathrm{~B}$ basalts are given in Table 3 and are plotted in Figures 2, 3, 4, and 5. $\mathrm{NiO}, \mathrm{CoO}, \mathrm{ZnO}$, and $\mathrm{V}_{2} \mathrm{O}_{3}$ were not determined, although they are likely to be present in small quantities. $\mathrm{Fe}^{2+} / \mathrm{Fe}^{3+}$ was estimated by calculation from total iron based on the assumption of perfect stoichiometry of the spinels $\left(\mathrm{R}^{++} \mathrm{R}^{2+++} \mathrm{O}_{4}\right)$.

Basalts from Hole $396 \mathrm{~B}$ have chromian spinels intermediate in composition between chromite $\left(\mathrm{Fe}^{2} \mathrm{Cr}_{2} \mathrm{O}_{4}\right)$ and spinel $\left(\mathrm{MgA}_{2} \mathrm{O}_{4}\right)$. As with most terrestrial chromian spinels, they have low $\mathrm{Fe}_{2} \mathrm{O}_{3}$ contents of 4.6 to 9.2 weight per cent. The $\mathrm{Cr} /(\mathrm{Cr}+\mathrm{A} 1)$ ratios are similar to those found for most other spinels from Mid-Atlantic Ridge basalts, but have decidedly higher iron content (Figure 3 ). This may refelct either a lower temperature of crystallization or a greater $\mathrm{Fe} 0$ content in the melt.

The most striking feature of the analyses is the large range in compositions found for individual spinels in a single thin section (Figure 4). The variation is erratic and at least two patterns are apparent. The most prominent is a large progressive increase of $\mathrm{Cr} /(\mathrm{Cr}+\mathrm{A} 1)$ with a small variation of $\mathrm{Mg} /\left(\mathrm{Mg}+\mathrm{Fe}^{2+}\right)$ e.g., Samples 396B-16-2, $40-42 \mathrm{~cm}$ and 16-5, 96-98 cm (cited as Samples 2 and 4) in Figure 4. The second trend is increasing $\mathrm{Fe}^{2+}$ and $\mathrm{Fe}^{3+}$ with variable $\mathrm{Cr} /(\mathrm{Cr}+\mathrm{A} 1)$. This trend is seen most clearly in zoned groundmass spinels in basalts from Unit 1, e.g., Samples 396B-8-2, 60-62 cm; 10-1, 51-53 cm; and 12-1, $127-129 \mathrm{~cm}$ in Figure 4.

Irvine (personal communication, 1977) has found two trends for spinels experimentally crystallized at one atmosphere from a basaltic melt: (1) decreasing $\mathrm{Cr} /(\mathrm{Cr}+\mathrm{A} 1)$ with co-precipitating olivine, and (2) increasing $\mathrm{Cr} /(\mathrm{Cr}+\mathrm{A} 1)$ with co-precipitating plagioclase and olivine. The partitioning of $\mathrm{Mg}$ and $\mathrm{Fe}^{2+}$ between olivine and spinel is temperature-dependent and crystallization at lower temperatures (or higher iron contents) shifts spinel to a more iron-rich composition (Irvine, 1967). Accordingly, the spinel zoning patterns observed in the three Unit 1 basalts are consistent with simple progressive crystallization of spinel with olivine or with plagioclase and olivine, and a consequent decrease in temperature and $\mathrm{Mg} /\left(\mathrm{Mg}+\mathrm{Fe}^{2+}\right)$ in the melt. 
TABLE 2

Hole 396B Olivine Analy ses, Unit 4

\begin{tabular}{|c|c|c|c|c|c|c|c|c|c|c|c|c|c|c|c|c|c|c|c|}
\hline \multirow{2}{*}{$\frac{\text { Sample }}{\text { Grain }}$} & \multicolumn{5}{|c|}{$16-1,86-83 \mathrm{~cm}$} & \multicolumn{3}{|c|}{$16-2,37-40 \mathrm{~cm}$} & \multicolumn{4}{|c|}{$16-5,95-97 \mathrm{~cm}$} & \multicolumn{4}{|c|}{$22-1,95-99 \mathrm{~cm}$} & \multicolumn{3}{|c|}{$\begin{array}{c}\text { Replicate Analyses (15) } \\
\text { Standard Olivine Grain (p. 140) }\end{array}$} \\
\hline & 1 & 2 & 3 & 4 & 5 & 1 & 2 & 3 & 1 & 2 & 3 & 4 & 1 & 2 & 3 & 4 & $\mathrm{x}$ & $1 \sigma$ & Quoted Analyses \\
\hline $\begin{array}{l}\mathrm{FeO} \\
\mathrm{MgO} \\
\mathrm{SiO}_{2} \\
\mathrm{CaO} \\
\mathrm{NiO}\end{array}$ & $\begin{array}{r}13.28 \\
46.48 \\
38.87 \\
0.32 \\
0.16\end{array}$ & $\begin{array}{r}12.78 \\
47.25 \\
38.82 \\
0.30 \\
0.16\end{array}$ & $\begin{array}{r}13.11 \\
46.80 \\
38.85 \\
0.32 \\
0.16\end{array}$ & $\begin{array}{r}13.22 \\
47.18 \\
38.46 \\
0.30 \\
0.15\end{array}$ & $\begin{array}{r}11.61 \\
48.04 \\
39.34 \\
0.30 \\
0.16\end{array}$ & $\begin{array}{r}11.03 \\
47.85 \\
39.33 \\
0.31 \\
0.22\end{array}$ & $\begin{array}{r}13.11 \\
46.63 \\
39.01 \\
0.32 \\
0.16\end{array}$ & $\begin{array}{r}13.59 \\
46.20 \\
38.38 \\
0.33 \\
0.18\end{array}$ & $\begin{array}{r}10.32 \\
49.06 \\
39.66 \\
0.31 \\
0.21\end{array}$ & $\begin{array}{r}12.77 \\
46.93 \\
39.07 \\
0.33 \\
0.18\end{array}$ & $\begin{array}{r}13.44 \\
46.46 \\
38.86 \\
0.31 \\
0.18\end{array}$ & $\begin{array}{r}14.33 \\
45.49 \\
38.59 \\
0.33 \\
0.16\end{array}$ & $\begin{array}{r}12.15 \\
46.74 \\
39.45 \\
0.32 \\
0.17\end{array}$ & $\begin{array}{r}10.70 \\
47.97 \\
39.81 \\
0.30 \\
0.17\end{array}$ & $\begin{array}{r}11.76 \\
47.13 \\
39.33 \\
0.32 \\
0.17\end{array}$ & $\begin{array}{r}11.59 \\
47.32 \\
39.61 \\
0.28 \\
0.20\end{array}$ & $\begin{array}{r}7.26 \\
52.02 \\
40.14 \\
- \\
0.30\end{array}$ & $\begin{array}{l}0.07 \\
0.53 \\
0.41 \\
- \\
0.02\end{array}$ & $\begin{array}{r}7.23 \\
51.63 \\
40.86 \\
- \\
-\end{array}$ \\
\hline Total & 99.1 & 99.3 & 99.2 & 99.3 & 99.4 & 98.7 & 99.2 & 98.7 & 99.6 & 99.3 & 99.3 & 98.9 & 98.8 & 99.0 & 98.7 & 99.0 & 99.73 & 0.42 & - \\
\hline $\begin{array}{l}\text { Fo } \\
\text { Grain } \\
\text { size }(\mathrm{mm}) \\
\text { Points } \\
\text { counted }\end{array}$ & $\begin{array}{l}86.2 \\
0.15 \\
4\end{array}$ & $\begin{array}{l}0.5 \\
5\end{array}$ & $\begin{array}{l}0.25 \\
7\end{array}$ & $\begin{array}{l}0.30 \\
4\end{array}$ & $\begin{array}{l}1.2 \\
9\end{array}$ & $\begin{array}{l}2.0 \\
3\end{array}$ & $\begin{array}{l}0.1 \\
4\end{array}$ & $\begin{array}{l}0.1 \\
3\end{array}$ & $\begin{array}{l}2.5 \\
3\end{array}$ & $\begin{array}{l}0.4 \\
5\end{array}$ & 86.0 & $\begin{array}{l}0.05 \\
3\end{array}$ & $\begin{array}{l}0.35 \\
6\end{array}$ & $\begin{array}{l}2.0 \\
6\end{array}$ & $\begin{array}{l}87.7 \\
0.07 \\
4\end{array}$ & $\begin{array}{r}87.9 \\
0.9\end{array}$ & 92.7 & 0.01 & 92.7 \\
\hline Shape & sb & eu & eu & eu & eu & eu & sb & & en & eu & eu & an & an & sb & eu & sb & & & \\
\hline Sample & & & & $-1,7-10$ & $\mathrm{~cm}$ & & & & 20- & .94-97 & & & & & & & & & \\
\hline Grain & 1 & 2 & 3 & 4 & 5 & 6 & 7 & 1 & 2 & 3 & 4 & 5 & & & & & & & \\
\hline $\begin{array}{l}\mathrm{FeO} \\
\mathrm{MgO} \\
\mathrm{SiO}_{2} \\
\mathrm{CaO} \\
\mathrm{NiO}\end{array}$ & $\begin{array}{r}13.14 \\
46.80 \\
38.82 \\
0.30 \\
0.14\end{array}$ & $\begin{array}{r}12.01 \\
47.57 \\
38.98 \\
0.32 \\
0.13\end{array}$ & $\begin{array}{r}12.57 \\
47.16 \\
38.87 \\
0.32 \\
0.13\end{array}$ & $\begin{array}{r}12.98 \\
47.29 \\
38.82 \\
0.32 \\
0.14\end{array}$ & $\begin{array}{r}13.04 \\
47.23 \\
39.16 \\
0.34 \\
0.19\end{array}$ & $\begin{array}{r}11.87 \\
48.11 \\
39.31 \\
0.31 \\
0.14\end{array}$ & $\begin{array}{r}13.61 \\
46.82 \\
38.33 \\
0.30 \\
0.16\end{array}$ & $\begin{array}{r}13.27 \\
46.45 \\
39.04 \\
0.28 \\
0.17\end{array}$ & $\begin{array}{r}12.39 \\
47.07 \\
39.43 \\
0.30 \\
0.16\end{array}$ & $\begin{array}{r}12.11 \\
47.14 \\
39.56 \\
0.28 \\
0.18\end{array}$ & $\begin{array}{r}12.35 \\
46.94 \\
39.49 \\
0.27 \\
0.17\end{array}$ & $\begin{array}{r}11.07 \\
47.95 \\
39.81 \\
0.30 \\
0.20\end{array}$ & & & & & & & \\
\hline Total & 99.2 & 99.0 & 99.1 & 99.6 & 100.0 & 99.7 & 99.2 & 99.2 & 99.3 & 99.3 & 99.2 & 99.3 & & & & & & & \\
\hline $\begin{array}{l}\text { Fo } \\
\text { Grain } \\
\text { size }(\mathrm{mm}) \\
\text { Points } \\
\text { counted }\end{array}$ & $\begin{array}{c}86.4 \\
1.2 \\
7\end{array}$ & $\begin{array}{r}87.6 \\
0.7\end{array}$ & 87.0 & $\begin{array}{r}86.7 \\
0.1\end{array}$ & $\begin{array}{c}86.6 \\
0.2\end{array}$ & $\begin{array}{r}87.8 \\
2.0\end{array}$ & $\begin{array}{r}86.0 \\
0.2\end{array}$ & $\begin{array}{r}86.2 \\
0.22\end{array}$ & $\begin{array}{c}87.1 \\
0.4 \\
3\end{array}$ & $\begin{array}{r}87.4 \\
0.5\end{array}$ & $\begin{array}{r}87.2 \\
1.8\end{array}$ & $\begin{array}{c}85.6 \\
1.8 \\
6\end{array}$ & & & & & & & \\
\hline Shape & $\mathrm{eu}$ & eu & eu & $\mathrm{eu}$ & eu & eu & eu & $\mathrm{cu}$ & an & eu & sb & & & & & & & & \\
\hline Sample & & $20-3,3$ & $5.39 \mathrm{~cm}$ & & & 21 . & 2. $24-27$ & & & & & & & & & & & & \\
\hline Grain & 1 & 2 & 3 & 4 & 1 & 2 & 3 & 4 & 5 & & & & & & & & & & \\
\hline $\begin{array}{l}\mathrm{YeO} \\
\mathrm{MgO} \\
\mathrm{SiO}_{2} \\
\mathrm{CaO} \\
\mathrm{NiO}\end{array}$ & $\begin{array}{r}11.20 \\
48.38 \\
39.14 \\
0.32 \\
0.20\end{array}$ & $\begin{array}{r}10.82 \\
48.55 \\
39.47 \\
0.31 \\
0.20\end{array}$ & $\begin{array}{r}12.68 \\
47.13 \\
39.32 \\
0.34 \\
0.18\end{array}$ & $\begin{array}{r}12.09 \\
47.68 \\
38.36 \\
0.31 \\
0.19\end{array}$ & $\begin{array}{r}12.29 \\
47.12 \\
39.43 \\
0.29 \\
0.18\end{array}$ & $\begin{array}{r}11.08 \\
47.98 \\
39.70 \\
0.25 \\
0.19\end{array}$ & $\begin{array}{r}12.27 \\
46.99 \\
39.57 \\
0.29 \\
0.17\end{array}$ & $\begin{array}{r}10.18 \\
48.77 \\
39.71 \\
0.28 \\
0.19\end{array}$ & $\begin{array}{r}11.66 \\
47.36 \\
39.71 \\
0.27 \\
0.14\end{array}$ & & & & & & & & & & \\
\hline Total & 99.2 & 99.3 & 99.7 & 98.6 & 99.3 & 99.2 & 99.3 & 99.1 & 99.1 & & & & & & & & & & \\
\hline $\begin{array}{l}\text { Fo } \\
\text { Grain } \\
\text { size }(\mathrm{mm}) \\
\text { Points } \\
\text { counted }\end{array}$ & $\begin{array}{c}88.5 \\
0.5 \\
4\end{array}$ & 88.9 & 86.9 & 87.6 & 87.2 & 88.6 & 87.3 & 89.5 & 87.9 & & & & & & & & & & \\
\hline Shape & eu & & $\mathrm{gdm}$ & eu & eu & an & sb & sb & $\mathrm{sb}$ & & & & & & & & & & \\
\hline
\end{tabular}

Notes: $\mathrm{eu}=$ euhedral, $\mathrm{sb}=$ subhedral, $\mathrm{an}=$ anhedral.

The spinel composition trends are less simple in the Unit 4 basalts. The crystallization history of the Unit 4 magma apparently was complex, as noted in a subsequent discussion, and it is possible that several generations of spinels may have been mixed together in the magma chamber to produce composite trends. Although the Unit 4 spinels occur with large amounts of co-precipitated plagioclase and olivine, the most prominent trend is a large increase in $\mathrm{Cr} /(\mathrm{Cr}+\mathrm{A} 1)$ with progressive crystallization, opposite to the findings of Irvine (personal communication). Large aluminous spinels, in fact, often have spongy margins apparently due to resorption. A similar trend from early, partially resorbed high-alumina to late euhedral high-chrome spinels has been found in some primitive $\mathrm{Mg}$-Ca basalt glasses from the FAMOUS region which have olivine but no plagioclase (Dick, 1976). Further, the aphyric Unit 1 basalts contain no high-alumina spinels, even though they may have undergone little plagioclase crystallization.

High-alumina spinels were first reported in Mid-Atlantic Ridge basalts by Bryan (1972) who suggested that their alumina contents indicate relatively high crystallization pressures. Frey et al. (1974), Sigurdsson and Schilling (1976), Dick (1976), and Sigurdsson (1977) have attributed high alumina contents of such spinels to crystallization at high pressures, noting their similarity to spinels in many mantle xenoliths. Experimental evidence for such a pressure effect was found by Green et al (1972) for spinels crystallized from lunar basalts. It is possible, therefore, that the high-A1 spinels in Leg 46 basalts are xenocrysts crystallized at higher pressures.

Spinel composition fields for different occurrences are shown in Figure 3. The majority of the Leg 46 basalts and abyssal tholeiites have spinels with $\mathrm{Cr} /(\mathrm{Cr}+\mathrm{A} 1)$ ratios between 0.42 and 0.55 . The similarity of the field for a few abyssal peridotites to that for the majority of spinels from abyssal tholeiites suggests that many abyssal peridotites are cumulates precipitated from the basalts. Alpine-type peridotites, of which the Josephine Peridotite (Figure 3) is representative, generally have a large range of $\mathrm{Cr} /(\mathrm{Cr}+\mathrm{A} 1)$ ratios, more restricted $\mathrm{Mg} /\left(\mathrm{Mg}+\mathrm{Fe}^{2+}\right)$ ratios than abyssal tholeiite spinels, and a restricted composition in a single 
TABLE 3

Chrome Spinel Analyses From DSDP Hole 396B Basalts

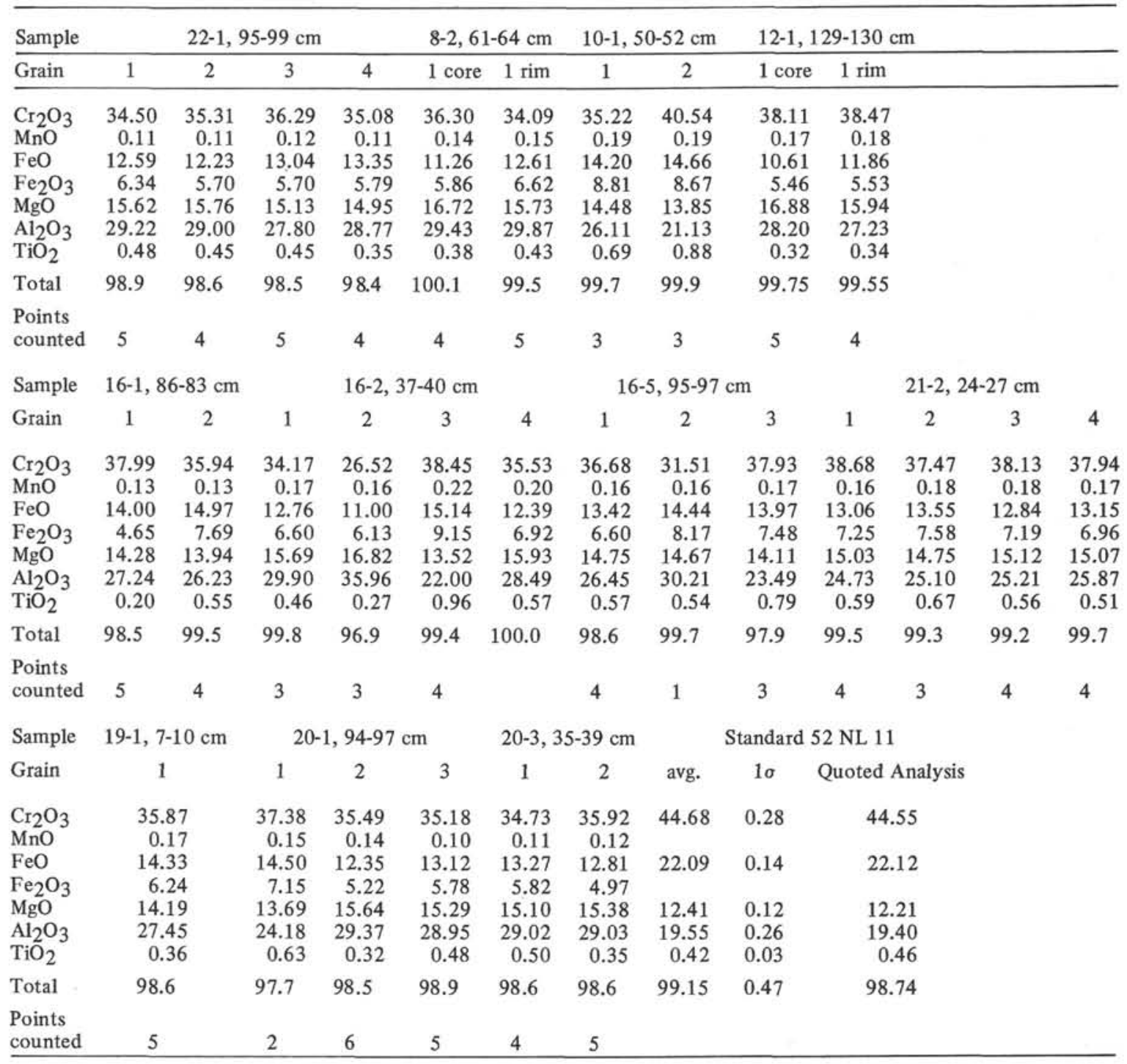

TABLE 4

Chemical Character of Spinel Bearing and Spinel Free Hole 396B Basalts

\begin{tabular}{lcccr}
\hline & \multicolumn{5}{c}{$\begin{array}{c}\text { Average } \\
\text { Basalt }\end{array}$} & $\mathrm{Cr}$ & $(\mathrm{FeO} *+\mathrm{MgO})$ & $\mathrm{Al}_{2} \mathrm{O}_{3}$ & $\mathrm{Al}_{2} \mathrm{O}_{3}{ }^{\mathrm{a}}$ \\
\hline Spinel & $337 \pm 21^{\mathrm{b}}$ & $52.5 \pm 2.6$ & $16.9 \pm 1.1$ & $15.6 \pm 0.4$ \\
Spinel free & $311 \pm 33$ & $55.0 \pm 1.2$ & $15.4 \pm 0.3$ & $15.4 \pm 0.3$ \\
\hline${ }^{\mathrm{a}}$ Excluding phenocryst-rich basalts. & & \\
$\mathrm{b}_{1 \sigma .}$
\end{tabular}

thin section. These differences undoubtedly reflect the re-equilibration of spinel to low temperatures in a slowly cooled mantle peridotite, while spinels in abyssal tholeiites reflect a range of conditions during crystallization and rapid cooling. It is interesting to note that in addition to more aluminous chromite ores (not shown in Figure 3), alpine-type peridotites have $\mathrm{Cr}$-rich chromite ores entirely outside the composition field of abyssal basalt and peridotite accessory spinels.
As shown in Figure 5, the Leg 46 basalt spinels also have higher $\mathrm{Fe}^{3+}$ contents than accessory spinel from alpine-type peridotites. The $\mathrm{Fe}^{3+} / \mathrm{Fe}^{2+}$ ratio of spinel is a function of $\mathrm{fO}_{2}$ which, in turn, is a function of temperature. Accordingly, the lower $\mathrm{Fe}^{3+}$ content of accessory spinels from alpine-type peridotites may reflect their equilibration to lower temperatures and a low relatively uniform $\mathrm{fO}_{2}$. The composition of spinel from the relatively massive podiform chromitite ores found within alpine-type peridotites, however, probably reflects more closely the conditions of their initial crystallization (Dick, 1977). These ores are thought to be residues precipitated from magmas that coalesced from and rose out of the mantle (e.g., Dick, 1977). The large range of $\mathrm{Fe}^{3+} / \mathrm{Fe}^{2+}$ found for spinels in basalts from Hole $396 \mathrm{~B}$, particularly in the same thin section, indicates a large variation if $\mathrm{fO}_{2}$ during the coarse of crystallization. Figure 6 suggests that $\mathrm{fO}_{2}$ varied from that at which podiform chromities crystallized in the mantle to much higher values, perhaps due to interaction with crustal water or to progressive fractional crystallization of the melt. 


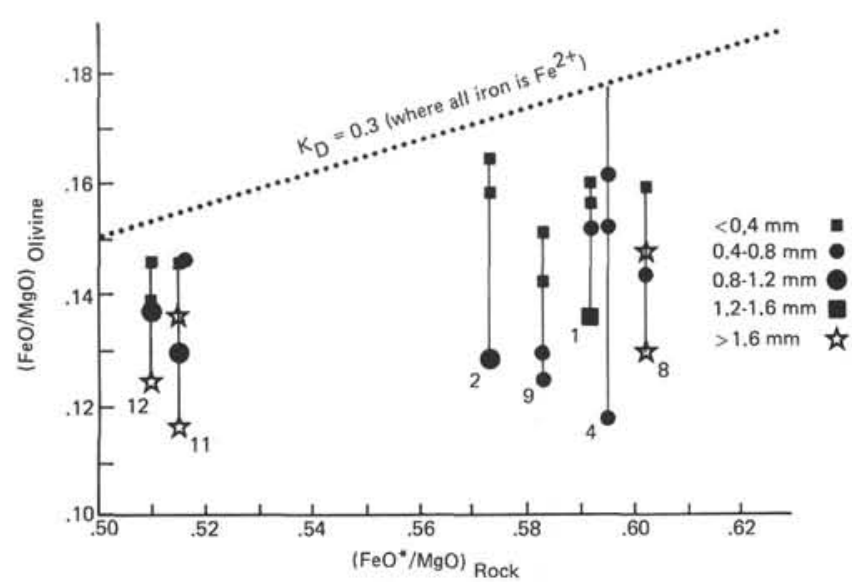

Figure 1. $(\mathrm{FeO} * / \mathrm{MgO})$ basalt versus $(\mathrm{FeO} / \mathrm{MgO})$ olivine for Hole $396 B$ basalts from Unit 4. Numbers are internal sample numbers given in Table 1. Symbols indicate phenocryst size. The dotted lines represent equilibrium olivine compositions if all iron is $\mathrm{Fe}^{2+}$. Departures from this line of microphenocryst compositions must largely be due to variable amounts of $\mathrm{Fe}^{3+}$ in the melt at the time of crystallization.

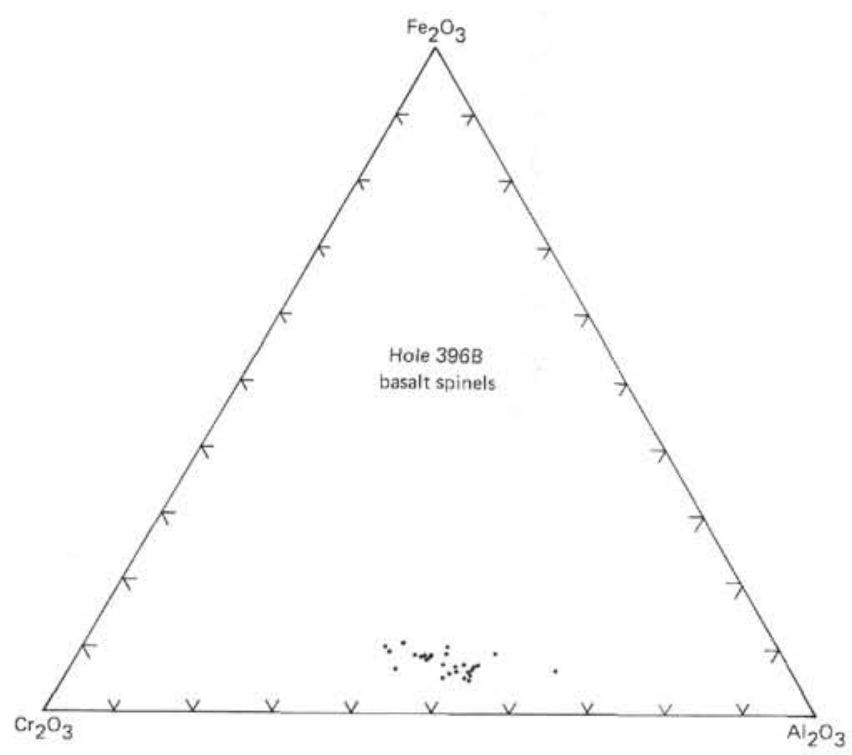

Figure 2. Plot of $\mathrm{R}^{+++}$components for spinels $\left(R^{+++} R_{2}{ }^{+++} O_{4}\right)$ from Hole $396 B$ basalts.

\section{COMPOSITION AND PHENOCRYST PROPORTIONS}

The range of variation in basalt compositions represented by the Hole $396 \mathrm{~B}$ basalts is small compared to the total variation of abyssal tholeiites, or to basalts recovered in the FAMOUS region of the Mid-Atlantic Ridge. So-called "primitive" $\mathrm{MgCa}$ and Ti-poor basalts (Melson et al., 1976) and relatively fractionated FeTi basalts (Melson et al., 1976), representing the known compositional extremes, are entirely absent at Site 396.

The normative compositions of 39 basalts from Hole $396 \mathrm{~B}$, calculated from the shipboard analyses, are plotted in Figure 6. Tie lines connect these points to the point along the plagioclase-olivine join representative of their modal

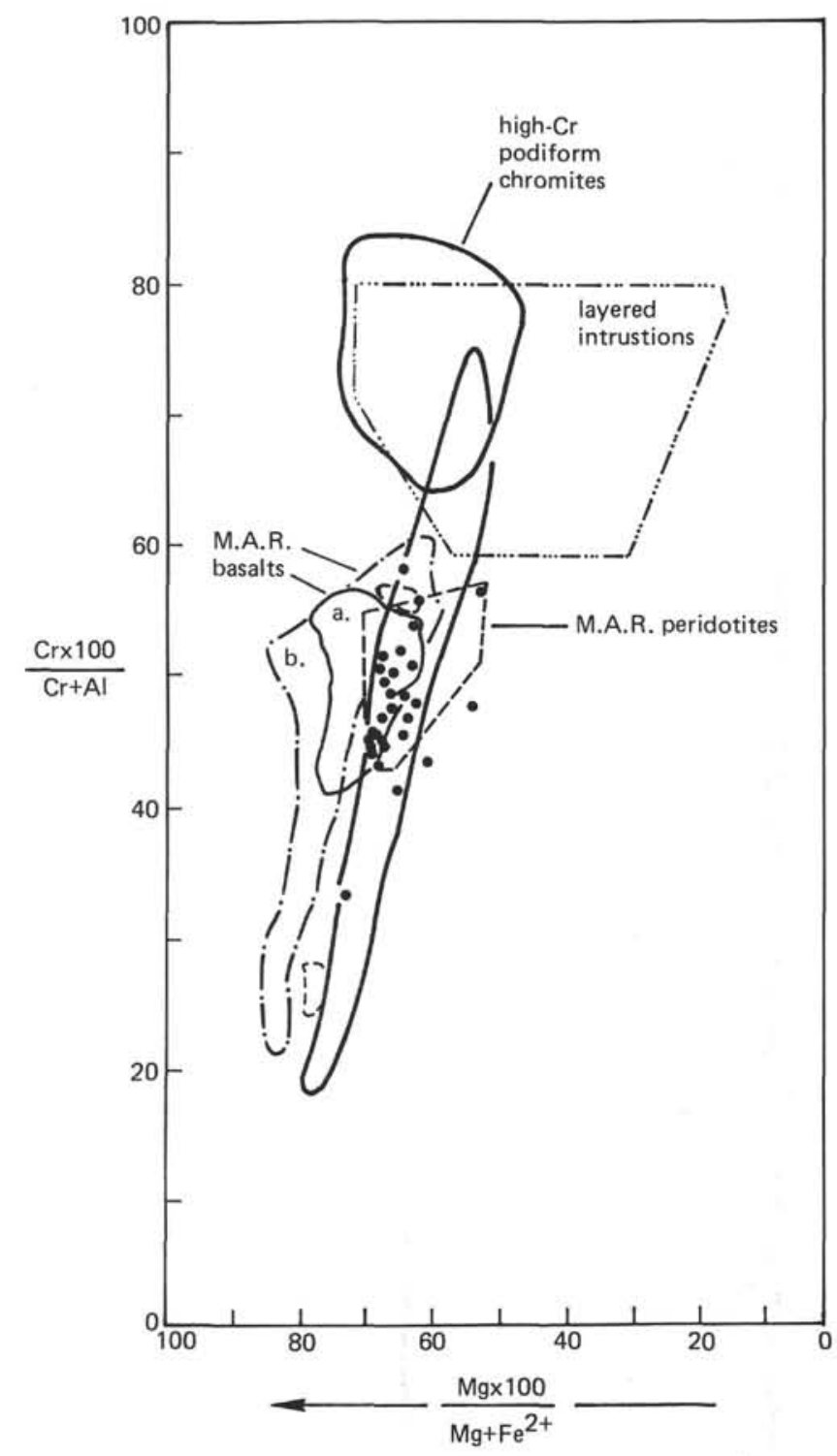

Figure 3. Plot of $R^{++}$versus Principal $R^{+++}$components for spinels from Hole 396 B basalts. Composition fields are given for Mid-Atlantic Ridge basalts. (a) MidAtlantic Ridge, Sigurdsson Schilling, 1976; (b) FAMOUS basalts (Dick, 1976), layered intrusions (Irvine, 1967), high-Cr podiform chromite ores (high-Al ores not shown) and alpine harzburgite spinels from the Josephine Peridotite (Dick, 1977), and Mid-Atlantic Ridge peridotites (Aumento and Loubat, 1971; Dick, unpublished data) are given for comparison.

phenocryst proportions (volume \%). The total modal phenocryst content of each sample is indicated along the join. Note that basalts which contain predominantly olivine phenocrysts are almost aphyric (bulk composition $\approx$ liquid compositions), while plagioclase is dominant in most of the phenocryst-enriched basalts. A similar relation was reported by Bryan and Moore (1977) for FAMOUS basalts.

With the exception of Units 4 and 7 (which contain large amounts of phenocrysts) and the slowly cooled comparatively coarse-grained Unit 3 cooling unit, the Hole $396 \mathrm{~B}$ basalts all lie quite close to a single line. The best-fit 


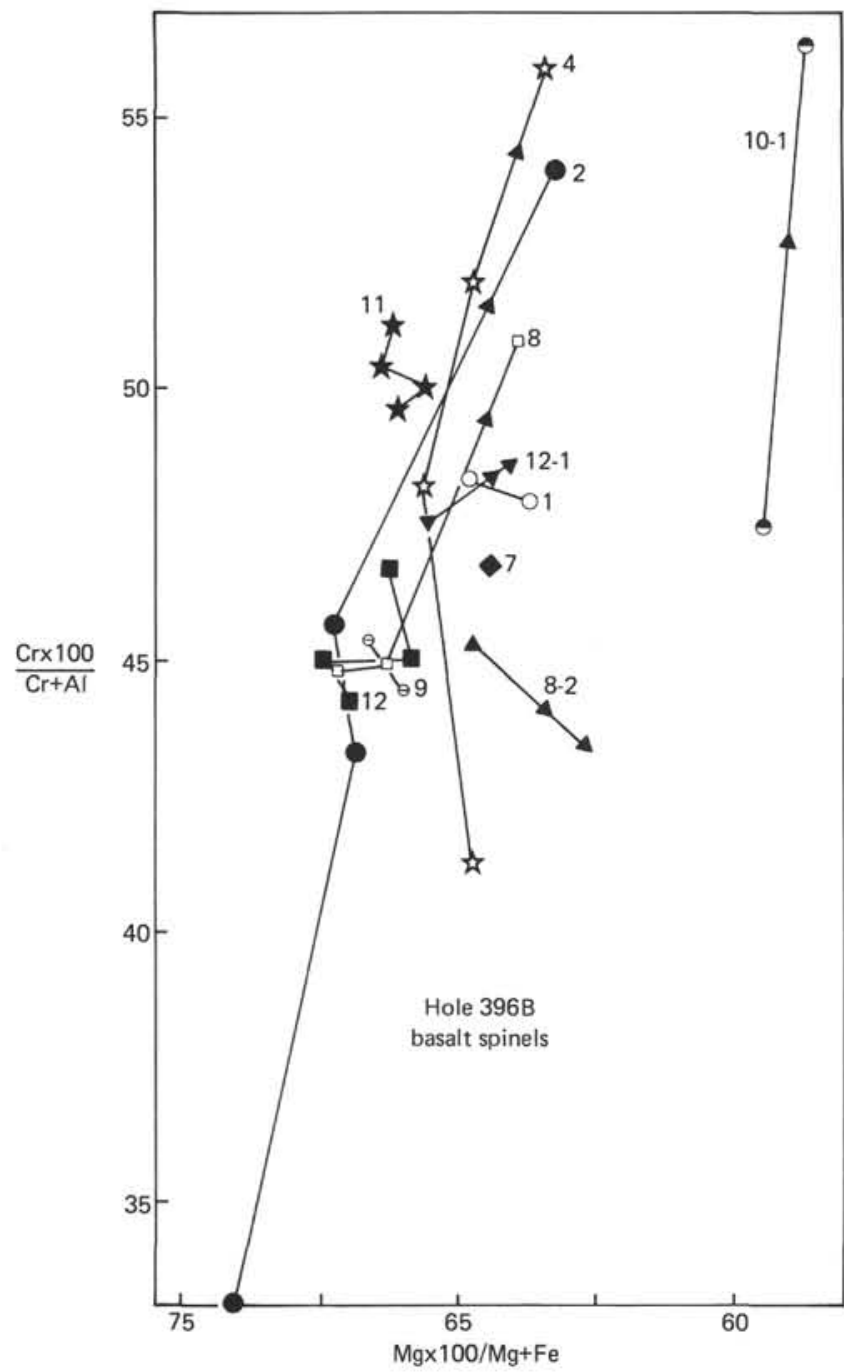

Figure 4. Blow-up of Figure 3 showing range in spinel Compositions in individual thin sections. Hyphenated numbers are sample numbers, others are internal sample numbers for Unit 4. Arrows indicate last crystallized spinel (crystallization trend) where petrographic criteria are available. Points for 8-1, 10-1, and 12-1 represent separate analyses of core and rim from a single grain.

line to these points (Figure 7) lies in a position close to that of the experimentally determined cotectic in the ternary system Fo-Di-An (Osborn and Tait, 1952) and is similar to the liquidus boundaries inferred for abyssal tholeiites by Miyashiro et al. (1970), and for FAMOUS basalt glasses (Figure 7[A]).

The Unit 4 (and Unit 7) plagioclase-olivine basalts lie on the plagioclase side of the inferred cotectic boundary. In Figure $7 \mathrm{~b}$, the proportions of phenocrysts have been recalculated to weight per cent from Figure 6 and used to project the basalts to their phenocryst-free compositions in the ternary. With one exception, ${ }^{2}$ the projected

\footnotetext{
${ }^{2}$ Section 396B-16-1 contains exceptionally coarse phenocrysts for which the modal analysis may not be representative of the small portion analyzed by $\mathrm{X}$-ray fluorescence.
}

compositions all lie along the cotectic inferred from the remaining relatively aphyric basalts from Hole 396B. As Miyashiro et al (1970) suggested, this indicates that crystallization and fractionation of the basalts was controlled by the cotectic at shallow levels. Crystallization may also have occurred at greater depths, as suggested by O'Hara (1968), or plagioclase since fractionation of olivine from an ascending magma would drive it toward the low pressure cotectic.

Despite the colinearity of the Hole 396B aphyric and phenocryst-free phyric basalt compositions, virtually none have phenocryst proportions expected for crystallization along the inferred cotectic $[\mathrm{Pg} /(\mathrm{Pg}+01) \approx 0.64]$. Rather, the basalts are rich in either olivine or plagioclase phenocrysts. This could reflect low phenocryst proportions and non-representative thin sections; however, this is clearly not the case for Units 4 and 7 . This suggests separation of crystals during crystallization, most likely by flotation of plagioclase and sinking of olivine.

The excess plagioclase in basalts from Unit 4 may be due to loss of co-precipitating olivine or to accumulation of plagioclase. Titanium, however, decreases systematically with increasing phenocryst content in Unit 4 basalts. This is the reverse of the trend expected for fractional crystallization, where $\mathrm{TiO}_{2}$ normally increases. Such a pattern might emerge, however, in a suite of magmas erupted from different parts of the same magma chamber where some magmas are $\mathrm{TiO}_{2}$-rich as a result of loss of phenocrysts and others are $\mathrm{TiO}_{2}$-poor where $\mathrm{TiO}_{2}$-poor phenocrysts have accumulated due to gravitational sorting of crystals.

Many of the differences between the compositions of basalts from Unit 4 and those from other units might be accounted for by the excess plagioclase in Unit 4 basalts. Specifically, the high $\mathrm{Al}_{2} \mathrm{O}_{3}$ contents in Unit 4 basalts might result from plagioclase accumulation. A least-squares regression line through all the points in Figure 8, however, yields a $\mathrm{TiO}_{2}$ content of -0.62 weight per cent at 100 per cent phenocrysts. This unlikely situation indicates that there are real differences in the liquid compositions of the different Hole 396B basalt units, differences due to factors other than phenocryst accumulation. These differences may reflect primary differences in magma compositions: fractionation of a parent liquid to different liquids; or a complex combination of random mixing, fractionation, and eruption of magmas from a chamber(s) over a period of time.

\section{VARIATION OF ROCK AND OLIVINE COMPOSITIONS}

Roeder and Emslie (1970) found that the $\mathrm{FeO} / \mathrm{MgO}$ ratio of olivine in equilibrium with a liquid is independent of temperature and is a function of the $\mathrm{FeO} / \mathrm{MgO}$ ratio of the melt.Using Roeder and Emslie's partition coefficient, Irvine and Findlay (1972) calculated the change in melt composition with percent olivine crystallization. Using Irvine and Findlay's (1972) diagram in reverse, one can estimate that for an average ocean tholeiite, the per cent olivine crystallization represented by the average range of olivine compositions in basalts from Unit 4 is about 8 per cent. This contrasts with the average of 3.1 per cent olivine 


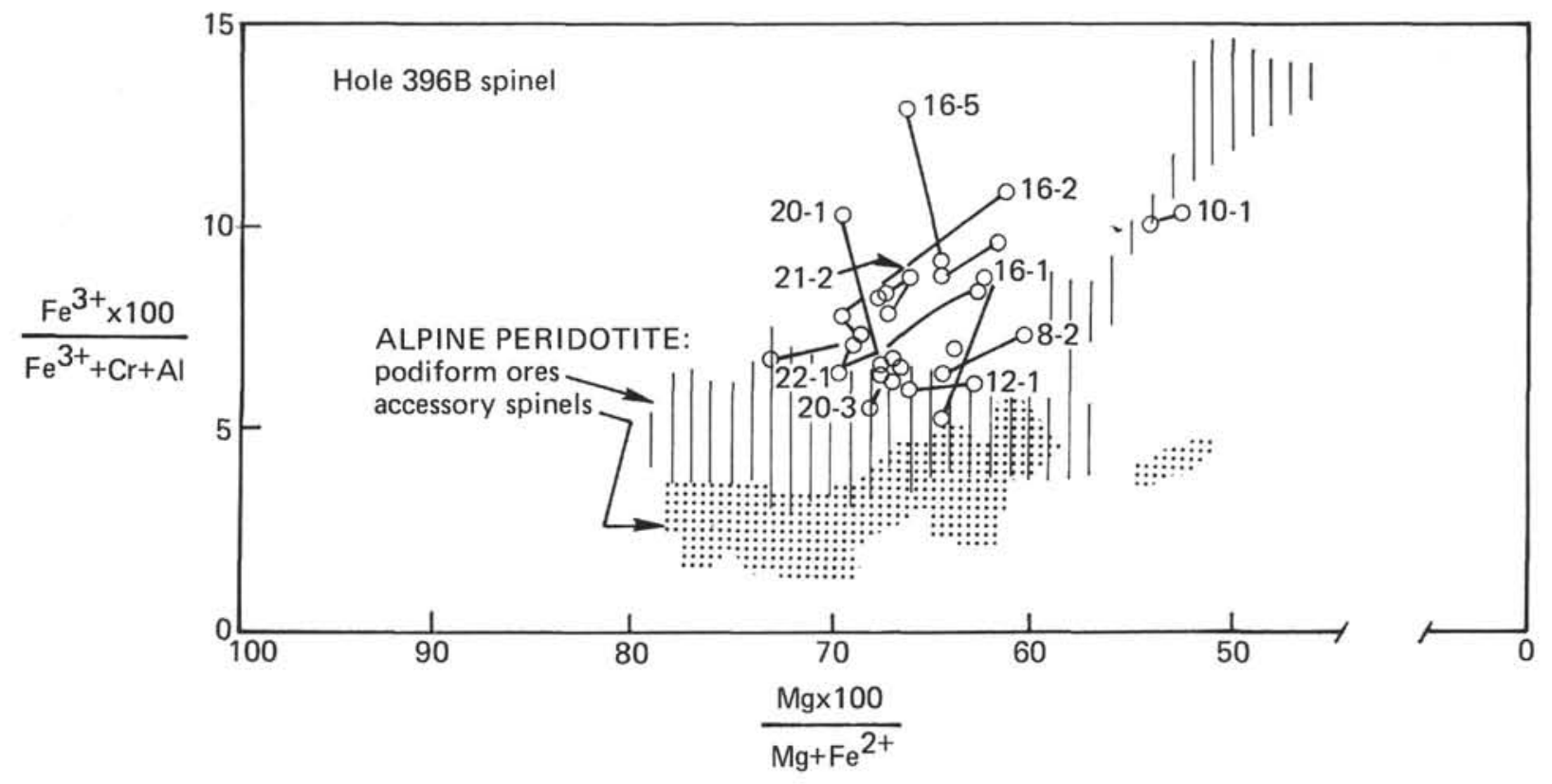

Figure 5. Plot of $R^{3+}$ versus $R^{2+}$ component ratios for spinels from Hole $396 \mathrm{~B}$ basalts. Lines connect analyses from the same thin section. Sample numbers are the same as in Table 1. Fields for accessory spinel in harzburgite and podiform chromitite ores are for the Josephine Peridotite (Dick, 1977).

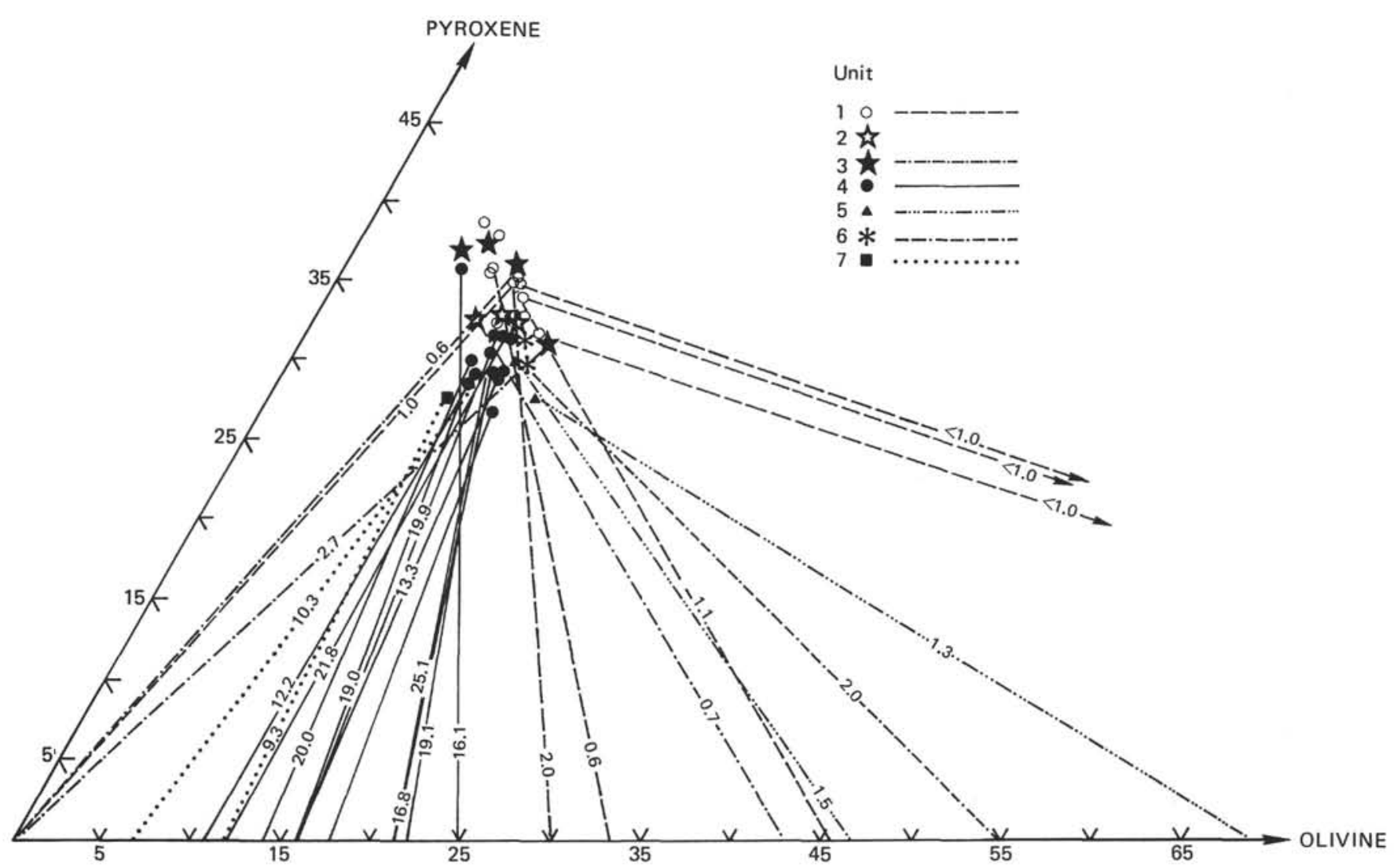

Figure 6. Corner of Px-Pg-01 ternary plotted with normative compositions (volume \%) of Hole 396B basalts. Lines connect these points to the Pg-01 join to indicate proportions of phenocrysts in the basalts and the modal phenocryst contents are given on the joins. Arrows point to $100 \%$ olivine. 


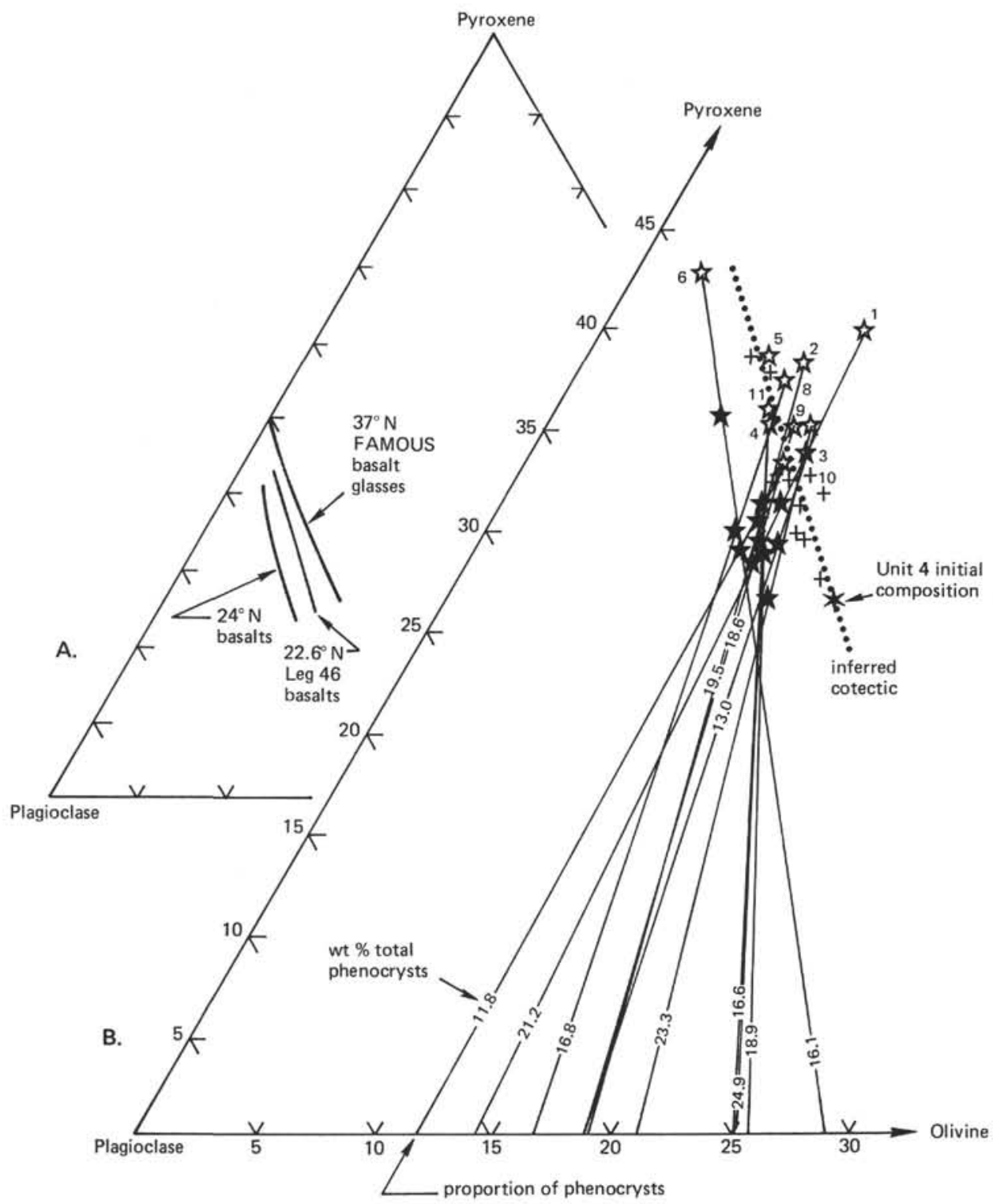

Figure 7. (A) Pg-01-Px ternary with lines of organic correlation calculated for Leg 46 aphyric basalts and FAMOUS basalt glasses, and line drawn by Miyashiro (1970) between plagioclase and olivine tholeiites. (B) Blow-up of the plagioclase corner of the $P g-01-P x$ normative ternary with all data recalculated to weight percent instead of volume percent. Dotted line represents the inferred cotectic boundary based on the relatively aphyric unit one, five and six basalts (same as in A) indicated by crosses. Coarsely crystalline Unit 3 basalts and phenocryst-rich basalts were excluded in calculating the line. Solid stars indicate Unit 4 basalt compositions. Open stars indicate projected Unit 4 phenocryst-free compositions.

phenocrysts found in these basalts. Thus, presuming initial equilibrium crystallization, one cannot account for the range of olivine compositions in Unit 4 basalts by their present olivine phenocryst content. The basalts must have either fractionated-out olivine or incorporated additional olivine by mixing of magmas and their phenocrysts, or by disaggregation of older rocks.

Using the proportion of olivine indicated by the range of olivine phenocryst compositions and the average plagioclase phenocryst content of the Unit 4 basalt yields a
$\mathrm{Pg} /(\mathrm{Pg}+01)$ ratio of 0.65 for the proportions of phenocrysts that crystallized from the Unit 4 magma. This is virtually the same proportion as that expected for shallow-level crystallization along the inferred cotectic in Figure 7 (0.64). This could indicate that the Unit 4 basalt magma crystallized olivine and plagioclase at a shallow level, fractionating olivine. It also suggests that the average Unit 4 basalt contains a representative proportion of the plagioclase phenocrysts crystallized from the Unit 4 magma prior to eruption. 


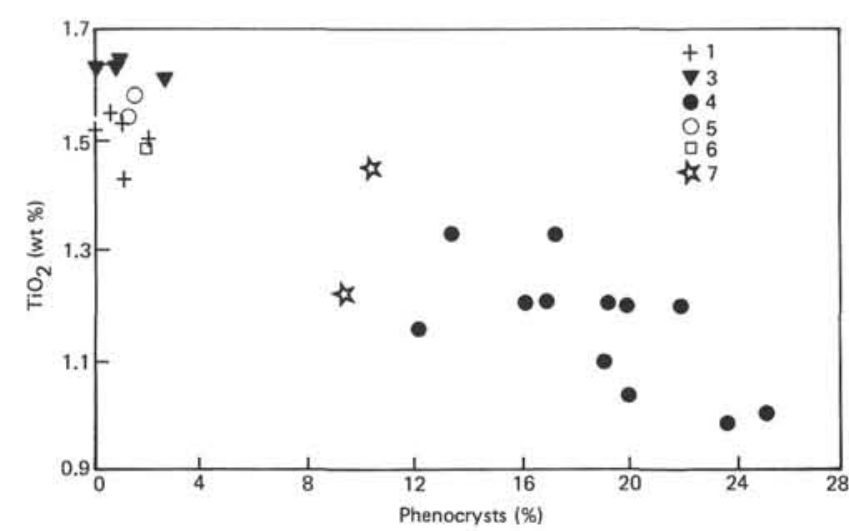

Figure 8. Plot of $\mathrm{TiO}_{2}$ contents of Hole $396 \mathrm{~B}$ basalts versus their phenocryst proportions.

It is not possible to rule out disaggregation of older rock as the source of some of the Unit 4 phenocrysts. Disaggregation of an older rock, however, should produce an excess proportion of phenocrysts in the melt as a consequence of the heat loss required for disaggregation (Anderson, 1976). Projecting the average Unit 4 basalt back along the cotectic a distance corresponding to crystallization of 14.6 weight per cent plagioclase and 8 weight per cent olivine yields an initial liquid scarcely more mafic than the most mafic Hole $396 \mathrm{~B}$ basalt and well within the range of Mid-Atlantic Ridge basalt compositions. Thus, the phenocryst content of the Unit 4 basalts can be explained by simple crystallization from a relatively mafic parent. The bulk of the Unit 4 phenocrysts could be explained by disaggregation of older rock only if the phenocryst content and composition of the disaggregated rock were similar to those of the intruding melt. Due to disproportionation of phenocrysts during crystallization, it would be fortuitous if disaggregated wall rocks contained the same phenocryst proportions as that crystallizing from the intruding magma. The absence of excess phenocrysts and the lack of xenoliths in the Unit 4 basalts, suggest that significant amounts of disaggregation are unlikely to have occurred.

Plotted in Figure 1 is the line representing equilibrium olivine and melt compositions based on Roeder and Emslie's partition coefficient. It is reasonable to assume that small euhedral microphenocrysts $(<0.4 \mathrm{~mm})$ now found in the basalts were in equilibrium with the melt at the time of eruption. As expected, the olivine microphenocrysts plot below the line in Figure 1, obviously reflecting $\mathrm{Fe}^{2+}<\mathrm{Fe}$ total and a significant, highly variable $\mathrm{Fe}_{2} \mathrm{O}_{3}$ content in the melt at the time of eruption. Subtracting the $\mathrm{FeO}$ and $\mathrm{MgO}$ content of the phenocrysts from the whole rock analysis only increases the amount of $\mathrm{Fe}_{2} \mathrm{O}_{3}$ in the melt suggested by the microphenocryst compositions.

It is reasonable to assume that the $\mathrm{Fe}^{3+} / \mathrm{Fe}^{2+}$ ratio of melt was largely a function of $\mathrm{fO}_{2}$. Variation of $\mathrm{fO}_{2}$ in the melt might be produced by progressive fractional crystallization or interaction between the melt and water trapped in the crust. Both of these, however, should act to progressively increase $\mathrm{fO}_{2}$ in the melt. Alternatively, recent experimental work on fluid inclusions in xenocrystal olivine from oceanic basalts (Delaney et al., 1977) suggests that the $\mathrm{fO}_{2}$ of "primary" mantle derived magmas is very low. The large "irregular variation in $\mathrm{Fe}_{2} \mathrm{O}_{3}$ " indicated by the olivine microphenocrysts from Unit 4 plotted in Figure 1 may suggest intermittent feeding of the magma chamber by less fractionated magmas.

\section{SUMMARY AND CONCLUSIONS}

The Hole 396B stratigraphic sequence contains a number of distinctly different pillow basalt units. Their boundaries are marked by abrupt changes in mineralogy and chemistry, and often coincide with weathering and sediment deposition, and a change in magnetic inclination. Given the predominance of pillow lavas, the Hole 396B suite is largely surface flows in stratigraphic sequence of their eruption. It appears, then, that they represent periodic volcanism with intervening eruptive hiatuses marked by sedimentation and weathering.

There is no systematic variation in chemistry and mineralogy through the sequence of units that can be explained by simple progressive fractional crystallization in a magma chamber of a single batch of parent liquid. It can be seen in Figure 6, in fact, that each of the different units has basalts with a range of compositions overlapping those of the other units. Relatively mafic compositions often lie late in the Hole 396B sequence, and intra-unit variations may be irregular or the reverse of those expected for simple fractionation.

It is evident, from the variation of whole rock compositions and phenocryst mineralogy, that crystallization of the pillow basalts was controlled at shallow levels by a cotectic and that gravitational sorting of crystals in the liquid occurred prior to eruption. In the case of Unit 4, we can infer that olivine and plagioclase crystallization was extensive (about 22 weight per cent) along this low-pressure cotectic. The negative correlation of phenocryst proportions and whole rock $\mathrm{TiO}_{2}$ contents suggests that accumulation of plagioclase and loss of olivine, or the reverse, occurred in the different Unit 4 basalts. All of this can be explained by derivation of the surface flows from different portions of a shallow magma chamber, including the irregular intra-unit stratigraphic variations of phenocryst proportions and compositions and whole rock chemistry. It is a common observation from volcanic stratigraphy that some magma chambers appear to have emptied from bottom to top, some from top to bottom, and others randomly.

The large variation of phenocryst compositions, and their different glass inclusions in a single pillow, can be explained by mixing early and late-formed olivine and plagioclase. It is well-known that crystals accumulated at the bottom or top of a chamber undergo little growth from the interstitial liquid due to a low ratio of liquid to crystals. In this manner, early formed crystals can be preserved. Turbulence accompanying eruption may mix these with later-formed crystals, both in the eruptive unit and in the chamber itself. This phenomenon should give rise to complex co-existing growth patterns such as are observed in many of the Leg 46 thin sections.

The presence of both normal and reverse zoning and different glass inclusion compositions in some Hole 396B basalts could be explained as the result of incorporation of 
crystals from disaggregated wall rocks. The proportion of olivine thought to have crystallized from many of these basalts and the observed plagioclase phenocryst content, however, is that expected for crystallization along the low pressure cotectic from a reasonable parent composition. The remaining Hole 396B basalts have low phenocryst contents which would not be expected if they had disaggregated appreciable amounts of wall rocks.

Mixing of magmas and their phenocrysts may also explain different glass inclusion and normal and reverse zoning of crystals in many Hole 396B basalts (Dugan et al., this volume). As discussed in this paper, it is also a means of explaining irregular variations in melt composition, $\mathrm{fO}_{2}$ (as indicated by olivine microphenocryst and spinel compositions), and the presence of possible high-pressure Al-rich spinel xenocrysts.

Magma mixing, however, is a term which can encompass a multitude of sins. One might explain many of the features observed in the Hole $396 \mathrm{~B}$ basalts as the product of intermittent feeding of a magma chamber with fresh mantle-derived melt during the eruptive cycle with a complete homogenization of the two. This is not likely to be the case. We view the intermittent volcanic activity in Iceland and Hawaii as analogous to the situation at Hole 396B. In these regions, a given volcanic episode, such as might produce one of the Hole $396 \mathrm{~B}$ pillow basalt units, is relatively short; eruptions generally occur over a period of days to a year. The introduction of a single batch of new melt into a magma chamber is likely to give rise to liquid heterogeneities in the chamber which last the duration of the eruptive episode. Thus, flows from different parts of the chamber and turbulence accompanying eruption could give rise to all the chemical and mineralogic variations seen in individual Hole 396B pillow basalt units.

The data suggest, then, the presence of a magma chamber(s) at some depth beneath a ridge axis. This chamber appears to have been fed intermittently by new magma either from a deeper chamber or directly from the mantle. Crystallization within the chamber, sometimes extensive, was controlled by the cotectic with gravitational sorting of precipitated olivine and plagioclase. In addition to variation in phenocryst proportions, the chamber could also have been zoned or heterogeneous with respect to melt composition. Disaggregation of wall rocks was probably a minor process at best. The abrupt changes in chemistry and mineralogy and the presence of sediment and weathering at the upper contacts of the Hole 396B basalt units indicates that eruption from the chamber(s) was periodic. A possible control may have been intermittent earthquake and rifting episodes along the ridge axis. The differences between the major pillow basalt units are the likely consequence of random combinations of fractional crystallization and introduction of new magma, or of the formation of a new magma chamber between eruptive episodes.

\section{ACKNOWLEDGMENTS}

We would like to thank the officers and crew of the R/V GLOMAR CHALLENGER. In addition, we would like to acknowledge helpful reviews of the manuscript by Dr. Geoffrey Thompson of the Woods Hole Oceanographic Institution and Dr. James Kirkpatrick of the Deep Sea Drilling Project. This work was supported by the National Science Foundation (OCE 76-21967). We would also like to thank Angela Sousa and Mary Berry for typing and editing several versions of the manuscript.

\section{REFERENCES}

Anderson, A.T., 1976. Magma mixing: petrological process and volcanological tool, J. Volc. Geoth. Res., v. 1, p. 3-33.

Aumento, F. and Loubat, H., 1971. The Mid-Atlantic Ridge near $45^{\circ} \mathrm{N}$. Serpentinized ultramafic intrusions, Canadian J. Earth Sci, v. 8, p. 631-663.

Bryan, W.B. and Moore, J.G., 1977. Compositional variations of young basalts in the mid-Atlantic ridge rift valley near $36^{\circ} 49^{\prime}$ N, Geol. Soc. Am. Bull, v. 88, p. 556-570.

Delaney, J.R., Muenow, D., Ganguly, J., Royce, D., 1977. Anhydrous glass-vapor inclusions from phenocrysts in oceanic tholeiitic pillow basalts, Trans. Am. Geophys. Union, v. 58, p. 96.

Dick, H.J.B., 1976. Spinel in fracture zone "B"' and median valley basalts, FAMOUS area, mid-Atlantic ridge, Trans. Am. Geophys. Union, v. 57, p. 341.

, 1977. Partial melting in the Josephine Peridotite I, the effect on mineral composition and its consequence for geobarometry and geothermometry, Am. J. Sci., v. 277, p. 801-832.

Frey, F.A., Bryan, W.B., and Thompson, G., 1974. Atlantic ocean floor: geochemistry and petrology of basalts from Legs 2 and 3 of the Deep Sea Drilling Project, J. Geophys. Res., v. 79 , p. $5507-5527$.

Green, D.H., Ringwood, A.E., Ware, N.G., and Hibberson, W.O., 1972. Experimental petrology and petrogenesis of Apollos 14 basalts, Proc. Third Lunar Sci. Conf., Geochim. Cosmochim. Acta, Suppl. 3, v. 1, p. 197-206.

Gutmann, J.T., 1977. Textures and genesis of phenocrysts and megacrysts in basaltic lavas from Pinacate volcanic field, $\mathrm{Am}$. J. Sci., v. 277, p. 833-861.

Hekinian, R., Moore, J. G., and Bryan, W. B., 1976. Volcanic rocks and processes of the mid-Atlantic ridge rift valley near $36^{\circ} 49^{\prime}$ N, Contrib. Mineralo. Petrol., v. 58, p. 83-110.

Irvine, T.N., 1967. The Duke Island ultramafic complex, southeastern Alaska. In Willie, P.J. (Ed.), Ultramafic and Related Rocks: New York (John Willie and Sons), p. 84-97.

Irvine, T.N. and Findlay, T.C., 1972. Alpine peridotite with particular reference to the Bay of Islands Complex. In The Ancient Ocean lithosphere: Ottawa, Canada (Dept. Energy, Mines and Resources, Earth Physics Branch), v. 43, p. 97-126.

Melson, W.G., Vallier, T.L., Wright, T.L., Byerly, G., and Nelen, J., 1976. Chemical diversity of abyssal volcanic glass erupted along the Pacific, Atlantic and Indian Ocean sea-floor spreading centers. In Geophysics of the Pacific Ocean Basin: Geophys. Mono. 19, Am. Geophys. Union, p. 351-367.

Miyashiro, A., Shido, F., and Ewing, M., 1970. Crystallization and differentiation in abyssal tholeiites and gabbros from mid-oceanic ridges, Earth Planet Sci. Lett., v. 7, p. 361-365.

O'Hara, M.J., 1968. Are ocean floor basalts primary magmas?, Nature, v. 220, p. 683-686.

Osborn, E.F. and Tait, D.B., 1952. The system diopside-forsterite-anorthite, Am. J. Sci. Bowen vol., p. 413.

Roeder, P.L. and Emslie, R.F., 1970. Olivine-liquid equilibrium, Contrib. Mineral. Petrol., v. 29, 275-289.

Sigurdsson, H., 1977. Spinels in Leg 37 basalts and peridotites: Phase chemistry and zoning. In Aumento, F., Melson, W.G., et al., Initial Reports of the Deep Sea Drilling Project, v. 37, Washington (U.S. Government Printing Office), p. 775-794.

Sigurdsson, H. and Schilling, J.G., 1976. Spinels in mid-Atlantic ridge basalts: Chemistry and occurrence, Earth Planet. Sci. Lett., v. 29, p. 7-20. 